\title{
Age and Gender Dependent Deposition of Crude Nutrients and Energy in Fast Growing Meat-Type Chickens
}

\author{
Christian Wecke, Frank Liebert \\ Division of Animal Nutrition Physiology, Department of Animal Sciences, Georg-August-University of Goettingen, Goettingen, \\ Germany \\ Email: flieber@gwdg.de
}

How to cite this paper: Wecke, C. and Liebert, F. (2019) Age and Gender Dependent Deposition of Crude Nutrients and Energy in Fast Growing Meat-Type Chickens. Open Journal of Animal Sciences, 9, 35-50.

https://doi.org/10.4236/ojas.2019.91004

Received: October 17, 2018

Accepted: December 18, 2018

Published: December 21, 2018

Copyright $\odot 2019$ by authors and Scientific Research Publishing Inc. This work is licensed under the Creative Commons Attribution International License (CC BY 4.0).

http://creativecommons.org/licenses/by/4.0/

c. (i) Open Access

\begin{abstract}
Two consecutive growth studies were conducted to investigate the age-dependent nutrient and energy deposition in male and female meat-type chickens (Ross 308) based on feather and feather-free body fraction data determined according to the comparative slaughter technique. Birds were reared under standardized housing conditions ( 15 floor pens per gender, 5 birds per pen). Both the starter (day 1 to 22) and grower diets (day 22 to 36) were based on corn, wheat, soybean meal, soybean protein concentrate and crystalline feed amino acids. Diets were formulated to ensure an equal feed protein quality close to the ideal amino acid ratio by adjusting a constant mixture of the feed proteins. Individual body weight (BW) and feed intake per pen were recorded weekly. At the start (day 1) as well as on a weekly basis until the end of the 5th week, 15 birds per gender (each 3 pens of 5 birds) were selected and euthanized following $24 \mathrm{~h}$ feed deprivation. Subsequently, the feathers were manually removed and quantified. Crude nutrient analysed in representative samples of both feather and feather-free body fractions. The nutrient and energy deposition in the bodies of both genders were significantly increased with increasing age $(p<0.001)$. Male birds deposited significantly higher body protein $(p<0.001)$ and female birds significantly more fat and energy in the whole body $(p<0.001)$ during the entire growth period. In contrast, no differences were found in protein contents of the BW gain between genders dependent on age $(p>0.05)$. However, the protein partitioning in the gain of both analyzed body fractions provided oppositional results. Accordingly, male birds yielded relatively more protein in the feather-free body fraction $(p<0.001)$ and females relatively more feather protein $(p<0.001)$ as related to the whole body protein gain.
\end{abstract}

\section{Keywords}

Growing Chickens, Growth Performance, Feed Deprivation, Empty Body 
Mass, Nutrient Deposition, Energy Deposition, Feather Protein Deposition, Age, Gender

\section{Introduction}

Over generations, poultry breeding has significantly improved performance data for broiler chickens [1] [2]. However in more recent years, fast selection progress has played an important role for the market meat yield by increasing the body protein deposition potential of present genotypes [3]. As already reported [4] [5], the body composition of recently produced broiler chickens has changed as compared to birds of earlier decades. Furthermore, it has been demonstrated that the nutrient content is considerably affected by the age and gender of the birds. Otherwise, research on the nutrient deposition in the whole body and body fractions of modern fast growing meat-type broiler chickens during the entire growth period is scarce. But the estimation of such data is continually required in the field of poultry nutrition in order to provide important information for the further optimization of nutrient supply and utilization.

Therefore, the present study primarily aimed to evaluate growth performance and feed efficiency data based on a well-balanced experimental feed mixture. The yielded data, completed by earlier published results on the age and gender dependent partitioning of the feather and feather-free body fraction [6] and their nutrient contents [4], have laid the foundations for estimating quantitative nutrient and energy deposition data for male and female birds per life week and growth period.

\section{Materials and Methods}

The study was conducted with 90 male and 90 female broiler chickens and performed at the facilities of the Division Animal Nutrition Physiology, Department of Animal Sciences at Georg-August-University Goettingen as approved by the Ethic Committee of the Lower Saxony Federal Office for Consumer Protection and Food Safety (LAVES), Germany. The methodical background has been described in detail in previous publications [4] [6], yet for further understanding the following modifications and additional information applied while working with the data in this study are included.

\subsection{Animals and Housing}

Freshly hatched meat-type broiler chicks (ROSS 308) were obtained from a commercial hatchery and allocated initially in a large floor pen on wood shavings. During the next day (d1) averaged weight birds were randomly divided into 15 pens per gender (each 5 birds per pen) and kept at environmentally-controlled conditions according to the Ross management recommendations [7] with unlimited access to feed and water. The growth experiment was divided into a 
starter ( $\mathrm{d} 1$ to $\mathrm{d} 22$ ) and grower period (d22 to d36). Further details were already reported elsewhere [6].

\subsection{Diets and Feeding}

The utilized starter and grower diet was based on corn, wheat and soybean meal, soybean protein concentrate and crystalline feed AAs as main ingredients [6]. Diet formulation aimed to meet or exceed current nutrient and energy recommendations for growing broiler chickens [8] [9] [10]. A constant mixture of utilized protein sources yielded equal feed protein quality during both of the feeding periods. The dietary AA concentrations were adjusted to closely match the ideal AA ratios [11].

\subsection{Collection and Sampling}

Both at the start of the experiment and weekly up to the end of the 5th week, 15 male and 15 female chickens (each 3 pens of 5 birds) were separately allocated for body composition analysis. Selected birds had continued free access to drinking water, but were fasted for 24 hours in order to empty their digestive tracts to yield an "empty body mass". Subsequently, these birds were euthanized by $\mathrm{CO}_{2}$ inhalation according to applicable German animal welfare regulations. Each sample of quantitatively collected feathers and of feather-free empty body was separately stored in plastic bags at $-20^{\circ} \mathrm{C}$ for further processing as previously described in detail [4] [6].

\subsection{Chemical Analyses}

Feed ingredients, experimental diets and the feather and feather-free empty body samples were analysed in duplicates according to method 3.1 (dry matter; DM) and 8.1 (crude ash; CA) of the German standard procedures of VDLUFA [12]. N content was measured by method 4.1.2 using the DUMAS principle (LECO $\mathrm{TruMac}^{\oplus}, \mathrm{LECO}$ Instrumente $\mathrm{GmbH}$, Mönchengladbach, Germany) and crude protein (CP) was calculated by a factor of 6.25 [12] [13]. The crude lipid (CL) content of both broiler body fractions was computed as remaining difference of DM after accounting for CA and CP [4].

\subsection{Performance Parameters}

Individual body weight (BW) and feed intake (FI) per pen were recorded at weekly intervals during the entire growth trial. Based on these data, the average BW gain (BWG) and feed conversion ratio (FCR; g FI/g BWG) per week, growth period and gender were estimated. The growth study started with 75 birds per gender, respectively. Based on the utilized comparative slaughter technique, at weekly intervals 30 birds ( 15 per gender, each 3 pens of 5 birds) were removed for body analysis. Accordingly, the number of birds continuously decreased up to the last experimental period at 5 weeks of age. Considering the already reported mean body nutrient composition of each corresponding reference groups 
[4], the nutrient deposition was determined by computing the difference between the crude nutrient content in the whole body of birds (feathers plus feather-free body) reared during the growth study at the end and the start of each week or growth period, respectively.The energy deposition was calculated using the factor $23.7 \mathrm{~kJ}$ per $\mathrm{g}$ accreted body protein and $39.8 \mathrm{~kJ}$ per $\mathrm{g}$ accreted body fat [14]. Additionally, the concentration of nutrients and energy in gained BW was estimated as the accreted amount in $\mathrm{g}$ or $\mathrm{kJ}$ per bird divided by the realized BWG (in $\mathrm{kg} / \mathrm{bird}$ ) within the individual age periods.

\subsection{Statistical Analyses}

Statistical analyses were conducted with SPSS software package (IBM SPSS Statistics Inc., Chicago, IL, USA; Version 24.0 for Windows). Two-way analysis of variance (ANOVA) was performed to compare means of calculated variables depending both on age and gender of broiler chickens as main effects, inclusive of their interactions. Verification of variance homogeneity was evaluated by the Levene-test. Significant differences $(p \leq 0.05)$ were identified both by Games-Howell and Tukey post-hoc tests.

\section{Results}

Based on the already reported age and gender dependent BW development of birds during the entire growth period [4], the corresponding mean daily FI, BWG and FCR data are summarized in Table 1. For all experimental parameters, highly significant differences $(p<0.001)$ for age and the interaction between age $\times$ gender were detected. This also applies to gender-specific BWG and FCR with advantages for male birds over their female counterparts, respectively. In contrast, no significant feed intake differences $(p>0.05)$ were observed between both genders.

Based on these zoo-technical results and the already reported body nutrient composition [4], the age and gender dependent nutrient and energy deposition data were calculated. The mean daily DM, CP, CL, CA and energy deposition in the whole body of broiler chickens (Table 2) was significantly increased with increasing age from week 1 to week $5(p<0.001)$, respectively. Whereas no gender-specific differences between the values of DM deposition were found $(p>$ $0.05)$, all crude nutrient and energy deposition data were significantly different between male and female birds $(p \leq 0.001)$. Accordingly, male chickens yielded higher CP and CA deposition, especially during the last three weeks. In contrast, female chickens developed consistently higher daily CL and energy deposition during the individual age periods as compared to their male counterparts. For all deposition data, significant interactions between age and gender were observed.

In order to determine the nutrient and energy contents in the gained BW from corresponding empty BW data [4], the BW loss of birds during the time of feed deprivation must be predicted. Table 3 summarizes the yielded whole and empty BW data depending on age and gender. As assumed, for both parameters 
Table 1. Zoo-technical data of broiler chickens per week, growth period and gender.

\begin{tabular}{|c|c|c|c|c|c|c|c|}
\hline \multirow{2}{*}{$\begin{array}{c}\text { Age } \\
\text { (week) }\end{array}$} & \multirow{2}{*}{$\mathrm{n}^{1}$} & \multicolumn{2}{|c|}{ Feed intake (g/d) } & \multicolumn{2}{|c|}{ Body weight gain $(\mathrm{g} / \mathrm{d})$} & \multicolumn{2}{|c|}{ Feed conversion ratio $(\mathrm{g} / \mathrm{g})$} \\
\hline & & Male & Female & Male & Female & Male & Female \\
\hline 1 & 15 & 21 & 24 & 19 & 22 & 1.15 & 1.06 \\
\hline 2 & 12 & 55 & 61 & 46 & 49 & 1.20 & 1.24 \\
\hline 3 & 9 & 96 & 96 & 80 & 75 & 1.19 & 1.28 \\
\hline $4^{2}$ & 6 & 140 & 138 & 97 & 89 & 1.44 & 1.56 \\
\hline $5^{3}$ & 3 & 185 & 170 & 125 & 107 & 1.48 & 1.59 \\
\hline Mean & & 97 & 98 & 72 & 68 & 1.28 & 1.35 \\
\hline $1-3^{4}$ & & 57 & 60 & 48 & 49 & 1.18 & 1.20 \\
\hline \multirow[t]{2}{*}{$4-5^{5}$} & & 160 & 154 & 110 & 98 & 1.46 & 1.57 \\
\hline & & \multicolumn{6}{|c|}{ Significance level $(p)$ of two-way ANOVA } \\
\hline \multicolumn{2}{|c|}{ Age (A) } & \multicolumn{2}{|c|}{$<0.001$} & \multicolumn{2}{|c|}{$<0.001$} & \multicolumn{2}{|c|}{$<0.001$} \\
\hline \multicolumn{2}{|c|}{ Gender (G) } & \multicolumn{2}{|c|}{0.078} & \multicolumn{2}{|c|}{0.003} & \multicolumn{2}{|c|}{0.001} \\
\hline \multicolumn{2}{|c|}{$A \times G$} & \multicolumn{2}{|c|}{$<0.001$} & \multicolumn{2}{|c|}{0.001} & \multicolumn{2}{|c|}{$<0.001$} \\
\hline
\end{tabular}

${ }^{1}$ Number of replications (pens of 5 birds) per gender and age period (week), respectively. ${ }^{2}$ One male bird died within week $4 .{ }^{3}$ Final body weight of male birds was determined $1 \mathrm{~d}$ earlier (see Table 3 ). ${ }^{4}$ Starter pe$\operatorname{riod}\left(\mathrm{d} 1\right.$ - d 22). ${ }^{5}$ Grower period (d 22 - d 36).

Table 2. Mean daily nutrient and energy deposition in the whole body of growing meat-type broiler chickens per week, growth period and gender.

\begin{tabular}{|c|c|c|c|c|c|c|c|c|c|c|c|}
\hline \multirow{2}{*}{ Age (week) } & \multirow{2}{*}{$\mathrm{n}^{1}$} & \multicolumn{2}{|c|}{ Dry matter $(\mathrm{g} / \mathrm{d})$} & \multicolumn{2}{|c|}{ Crude protein $(\mathrm{g} / \mathrm{d})$} & \multicolumn{2}{|c|}{ Crude lipids (g/d) } & \multicolumn{2}{|c|}{ Crude ash (g/d) } & \multicolumn{2}{|c|}{ Energy $(\mathrm{kJ} / \mathrm{d})^{2}$} \\
\hline & & Male & Female & Male & Female & Male & Female & Male & Female & Male & Female \\
\hline 1 & 15 & 4.2 & 5.3 & 2.8 & 3.3 & 1.0 & 1.6 & 0.3 & 0.4 & 107 & 142 \\
\hline 2 & 12 & 11.7 & 14.3 & 7.6 & 9.0 & 3.2 & 4.1 & 0.9 & 1.1 & 307 & 378 \\
\hline 3 & 9 & 22.1 & 21.7 & 14.9 & 13.4 & 5.3 & 6.6 & 1.9 & 1.7 & 566 & 579 \\
\hline $4^{3}$ & 6 & 30.8 & 29.4 & 19.4 & 17.5 & 8.8 & 9.7 & 2.6 & 2.1 & 810 & 802 \\
\hline $5^{4}$ & 3 & 35.4 & 36.9 & 24.2 & 20.7 & 8.3 & 14.0 & 2.8 & 2.3 & 904 & 1046 \\
\hline Mean & & 20.4 & 21.5 & 13.5 & 12.8 & 5.2 & 7.2 & 1.7 & 1.5 & 528 & 589 \\
\hline $1-3^{5}$ & & 12.7 & 13.7 & 8.5 & 8.5 & 3.2 & 4.1 & 1.0 & 1.1 & 327 & 366 \\
\hline \multirow[t]{2}{*}{$4-5^{6}$} & & 32.9 & 33.2 & 21.6 & 19.1 & 8.6 & 11.8 & 2.7 & 2.2 & 853 & 924 \\
\hline & & \multicolumn{10}{|c|}{$\underline{\text { Significance level }(p) \text { of two-way ANOVA }}$} \\
\hline \multicolumn{2}{|c|}{ Age (A) } & \multicolumn{2}{|c|}{$<0.001$} & \multicolumn{2}{|c|}{$<0.001$} & \multicolumn{2}{|c|}{$<0.001$} & \multicolumn{2}{|c|}{$<0.001$} & \multicolumn{2}{|c|}{$<0.001$} \\
\hline \multicolumn{2}{|c|}{ Gender $(G)$} & \multicolumn{2}{|c|}{0.139} & \multicolumn{2}{|c|}{0.001} & \multicolumn{2}{|c|}{$<0.001$} & \multicolumn{2}{|c|}{$<0.001$} & \multicolumn{2}{|c|}{$<0.001$} \\
\hline \multicolumn{2}{|c|}{$A \times G$} & \multicolumn{2}{|c|}{0.017} & \multicolumn{2}{|c|}{$<0.001$} & \multicolumn{2}{|c|}{$<0.001$} & \multicolumn{2}{|c|}{$<0.001$} & \multicolumn{2}{|c|}{0.010} \\
\hline
\end{tabular}

${ }^{1}$ Number of replications (pens of 5 birds) per gender and age period (week), respectively. ${ }^{2}$ Calculated according to [14], see 2.5. ${ }^{3}$ One male bird died within week $4 .{ }^{4}$ Final body weight of male birds was determined $1 \mathrm{~d}$ earlier (see Table 3$) .{ }^{5}$ Starter period (d 1 - d 22). ${ }^{6}$ Grower period (d 22 - d 36).

Table 3. Mean whole and empty body weight of growing broiler chickens depending on age and gender ${ }^{1}$.

\begin{tabular}{ccccccc}
\hline \multirow{2}{*}{$\begin{array}{c}\text { Age } \\
(\text { day })\end{array}$} & \multicolumn{2}{c}{ Whole body weight $(\mathrm{g})$} & \multicolumn{2}{c}{ Empty body weight ${ }^{2}(\mathrm{~g})$} & \multicolumn{2}{c}{ Empty body weight $^{2}(\% \text { of body weight })^{2}$} \\
\cline { 2 - 7 } & Male & Female & Male & Female & Male & Female \\
\hline 1 & 45.0 & 46.6 & 41.8 & 43.0 & 92.9 & 92.4 \\
8 & 170 & 194 & 146 & 169 & 85.7 & 87.2 \\
15 & 437 & 516 & 392 & 475 & 89.2 & 92.2 \\
22 & 959 & 1045 & 872 & 964 & 90.9 & 92.2 \\
$29^{3}$ & 1749 & 1655 & 1632 & 1534 & 93.3 & 92.8 \\
$36^{4}$ & 248 & 2438 & 2297 & 2279 & 92.3 & 93.4 \\
n & 89 & 90 & 89 & 90 & 99 & 90 \\
Mean & 966 & 982 & $\mathbf{8 8 9}$ & 911 & 90.7 & 91.7 \\
SD & 899 & 854 & 836 & 799 & 3.6 & 2.7 \\
\hline
\end{tabular}




\section{Continued}

\begin{tabular}{cccc}
\hline & \multicolumn{2}{c}{ Significance level $(p)$ of two-way ANOVA } & \\
Age (A) & $<0.001$ & $<0.001$ & $<0.001$ \\
Gender (G) & 0.629 & 0.349 & 0.003 \\
$\mathrm{~A} \times \mathrm{G}$ & 0.009 & 0.004 & 0.018 \\
\hline
\end{tabular}

${ }^{1} 15$ replications per gender and age group, respectively. ${ }^{2}$ Body weight following $24 \mathrm{~h}$ feed deprivation. ${ }^{3}$ One male bird died within week $4 .{ }^{4}$ Final body weight of male birds was determined at $35 \mathrm{~d}$ of age.

highly significant differences $(p<0.001)$ across ages were detected, but no gender-specific differences $(p>0.05)$ were observed. The empty BW, expressed as a percentage of the whole BW of the "full-fed" birds (free access to feed up to the time of feed withdrawal), varied between $86 \%$ and $93 \%$. Following these observations, the mean age dependent live weight loss of birds after $24 \mathrm{~h}$ of feed deprivation varied relatively marginally between $7 \%$ (d 29) and $9 \%$ (d 15), with the exception of $d 8$. At this age, data for both female and male birds depicted a significantly higher BW loss between $13 \%$ and $14 \%$ as compared to other age groups. Furthermore, significant interactions for all variables were detected between age and gender.

Based on the data listed in the previous tables, the age and gender dependent content of crude nutrients and energy in the gained BW of broiler chicken was estimated. All values (Table 4) consistently increased with increasing age ( $p<$ $0.001)$; although the corresponding data of male birds at 5 weeks did not exceeded those at 4 weeks. In addition, the individual CA concentrations in the BWG between weeks 3 and 5 underlay only a relatively low variation with slightly numerical advantages for male birds. Nevertheless, highly significant differences between individual values of both gender and the interaction of age $\mathrm{x}$ gender were observed $(p<0.001)$, with the exception of the CP contents in the gain of male and female birds $(p>0.05)$. In order to explain this observation based on already published data [4] [6], the age and gender dependent partitioning of the yielded protein deposition (PD) in the feather and feather-free body fractions was calculated, additionally. The results summarized in Table 5 explicitly indicate significant gender-specific differences $(p<0.001)$ between individual daily PD data in both of the body fractions. According to the considerably higher feather proportion in female birds [6], the mean daily PD in feathers of females exceeded the corresponding values of males. Conversely, the PD in the feather-free body of male birds was significantly higher as compared to females, especially at the end of the starter and during the entire grower period. In accordance with the previously mentioned accreted protein in the whole body of birds (Table 4), mean daily PD in both of the body fractions increased continuously with increasing age $(p<0.001)$. Equally, the feather protein proportion in the BWG for both genders was consistently increased by a factor of 4 from week 1 to 5 , with superior results for female birds $(p<0.001)$. In the present study, the protein gain in the feather-free body also significantly increased with age, but only up to the age of 4 weeks and only by a factor of 1.2 with higher values for male birds. 
Table 4. Composition of the body weight gain (BWG) of fast growing meat-type broiler chickens depending on age period and gender.

\begin{tabular}{|c|c|c|c|c|c|c|c|c|c|c|c|}
\hline \multirow{2}{*}{ Age (week) } & \multirow[t]{2}{*}{$\mathrm{n}^{1}$} & \multicolumn{2}{|c|}{ Dry matter (g/kg BWG) } & \multicolumn{2}{|c|}{$\begin{array}{l}\text { Crude protein } \\
\text { (g/kg BWG) }\end{array}$} & \multicolumn{2}{|c|}{$\begin{array}{l}\text { Crude lipids } \\
\text { (g/kg BWG) }\end{array}$} & \multicolumn{2}{|c|}{$\begin{array}{l}\text { Crude ash } \\
\text { (g/kg BWG) }\end{array}$} & \multicolumn{2}{|c|}{$\begin{array}{c}\text { Energy } \\
(\mathrm{MJ} / \mathrm{kg} \text { BWG) }\end{array}$} \\
\hline & & Male & Female & Male & Female & Male & Female & Male & Female & Male & Female \\
\hline 1 & 15 & 224 & 237 & 151 & 147 & 54 & 72 & 18 & 19 & 5.75 & 6.33 \\
\hline 2 & 12 & 257 & 292 & 167 & 184 & 70 & 85 & 21 & 23 & 6.72 & 7.75 \\
\hline 3 & 9 & 276 & 289 & 187 & 178 & 66 & 88 & 23 & 23 & 7.07 & 7.74 \\
\hline $4^{2}$ & 6 & 317 & 331 & 199 & 197 & 91 & 110 & 27 & 24 & 8.33 & 9.05 \\
\hline $5^{3}$ & 3 & 283 & 346 & 194 & 194 & 66 & 131 & 23 & 22 & 7.23 & 9.79 \\
\hline Mean & & 284 & 315 & 188 & 187 & 73 & 106 & 23 & 22 & 7.35 & 8.63 \\
\hline $1-3^{4}$ & & 263 & 282 & 176 & 175 & 66 & 85 & 22 & 22 & 6.78 & 7.52 \\
\hline \multirow[t]{2}{*}{$4-5^{5}$} & & 299 & 339 & 196 & 195 & 78 & 121 & 25 & 23 & 7.75 & 9.45 \\
\hline & & \multicolumn{10}{|c|}{ Significance level $(p)$ of two-way ANOVA } \\
\hline Age ( & & \multicolumn{2}{|c|}{$<0.001$} & \multicolumn{2}{|c|}{$<0.001$} & \multicolumn{2}{|c|}{$<0.001$} & \multicolumn{2}{|c|}{$<0.001$} & \multicolumn{2}{|c|}{$<0.001$} \\
\hline Gender & & \multicolumn{2}{|c|}{$<0.001$} & \multicolumn{2}{|c|}{0.076} & \multicolumn{2}{|c|}{$<0.001$} & \multicolumn{2}{|c|}{$<0.001$} & \multicolumn{2}{|c|}{$<0.001$} \\
\hline$A \times$ & & \multicolumn{2}{|c|}{$<0.001$} & \multicolumn{2}{|c|}{$<0.001$} & \multicolumn{2}{|c|}{$<0.001$} & \multicolumn{2}{|c|}{$<0.001$} & \multicolumn{2}{|c|}{$<0.001$} \\
\hline
\end{tabular}

${ }^{1}$ Number of replications (pens of 5 birds) per gender and age period (week), respectively. ${ }^{2}$ One male bird died within week $4 .{ }^{3}$ Final body weight of male birds was determined $1 \mathrm{~d}$ earlier (see Table 3). ${ }^{4}$ Starter period (d 1 - d 22). ${ }^{5}$ Grower period (d 22 - d 36).

Table 5. Daily protein deposition (PD) and protein gain as related to BWG in the feather and feather-free body fraction of growing broiler chickens depending on age period and gender.

\begin{tabular}{|c|c|c|c|c|c|c|c|c|c|c|c|}
\hline \multirow{2}{*}{$\begin{array}{l}\text { Age } \\
\text { (week) }\end{array}$} & \multirow{2}{*}{$\mathrm{n}^{1}$} & \multicolumn{2}{|c|}{ Mean body weight (g) } & \multicolumn{2}{|c|}{ PD in feathers $(g / d)$} & \multicolumn{2}{|c|}{$\begin{array}{l}\text { PD in feather-free body } \\
(\mathrm{g} / \mathrm{d})\end{array}$} & \multicolumn{2}{|c|}{$\begin{array}{l}\text { Feather protein } \\
\text { (g/kg BWG) }\end{array}$} & \multicolumn{2}{|c|}{$\begin{array}{l}\text { Feather-free body protein } \\
\text { (g/kg BWG) }\end{array}$} \\
\hline & & Male & Female & Male & Female & Male & Female & Male & Female & Male & Female \\
\hline 1 & 15 & 111 & 125 & 0.11 & 0.18 & 2.72 & 3.11 & 5.78 & 7.80 & 145.5 & 138.8 \\
\hline 2 & 12 & 337 & 376 & 0.35 & 0.74 & 7.27 & 8.26 & 7.68 & 15.07 & 158.9 & 169.1 \\
\hline 3 & 9 & 787 & 812 & 1.32 & 1.20 & 13.62 & 12.15 & 16.46 & 16.04 & 170.0 & 162.3 \\
\hline $4^{2}$ & 6 & 1422 & 1386 & 1.69 & 2.31 & 17.70 & 15.19 & 17.38 & 26.02 & 182.0 & 171.3 \\
\hline $5^{3}$ & 3 & 2107 & 2082 & 3.08 & 3.42 & 21.16 & 17.25 & 24.62 & 32.06 & 169.2 & 161.4 \\
\hline Mean & & 1267 & 1242 & 1.26 & 1.57 & 12.24 & 11.19 & 17.50 & 22.96 & 170.3 & 163.8 \\
\hline $1-3^{4}$ & & 551 & 558 & 0.59 & 0.70 & 7.87 & 7.84 & 12.30 & 14.45 & 163.3 & 161.0 \\
\hline \multirow[t]{2}{*}{$4-5^{5}$} & & 1773 & 1754 & 2.33 & 2.87 & 19.29 & 16.22 & 21.18 & 29.31 & 175.3 & 165.9 \\
\hline & & \multicolumn{10}{|c|}{$\underline{\text { Significance level }(p) \text { of two-way ANOVA }}$} \\
\hline \multicolumn{2}{|c|}{ Age (A) } & \multicolumn{2}{|c|}{$<0.001$} & \multicolumn{2}{|c|}{$<0.001$} & \multicolumn{2}{|c|}{$<0.001$} & \multicolumn{2}{|c|}{$<0.001$} & \multicolumn{2}{|c|}{$<0.001$} \\
\hline \multicolumn{2}{|c|}{ Gender (G) } & \multicolumn{2}{|c|}{0.640} & \multicolumn{2}{|c|}{$<0.001$} & \multicolumn{2}{|c|}{$<0.001$} & \multicolumn{2}{|c|}{$<0.001$} & \multicolumn{2}{|c|}{$<0.001$} \\
\hline \multicolumn{2}{|c|}{$A \times G$} & \multicolumn{2}{|c|}{$<0.017$} & \multicolumn{2}{|c|}{$<0.001$} & \multicolumn{2}{|c|}{$<0.001$} & \multicolumn{2}{|c|}{$<0.001$} & \multicolumn{2}{|c|}{$<0.001$} \\
\hline
\end{tabular}

${ }^{1}$ Number of replications (pens of 5 birds) per gender and age period (week), respectively. ${ }^{2}$ One male bird died within week $4 .{ }^{3}$ Final body weight of male birds was determined $1 \mathrm{~d}$ earlier (see Table 3 ). ${ }^{4}$ Starter period $(\mathrm{d} 1-\mathrm{d} 22) .{ }^{5}$ Grower period $(\mathrm{d} 22-\mathrm{d} 36)$. BWG = Body weight gain.

To better illustrate, Figure 1 depicts the relative partitioning of the protein gain in feathers of male and female birds at different age periods. The graph clearly demonstrates the progressively increasing of PD data in the feather fraction during the entire growth period associated with higher values for females. Accordingly, during the age period of 4 to 5 weeks a proportion between 13 and more than 16 percent of the whole daily PD was accreted in the feather of female broiler chickens. 


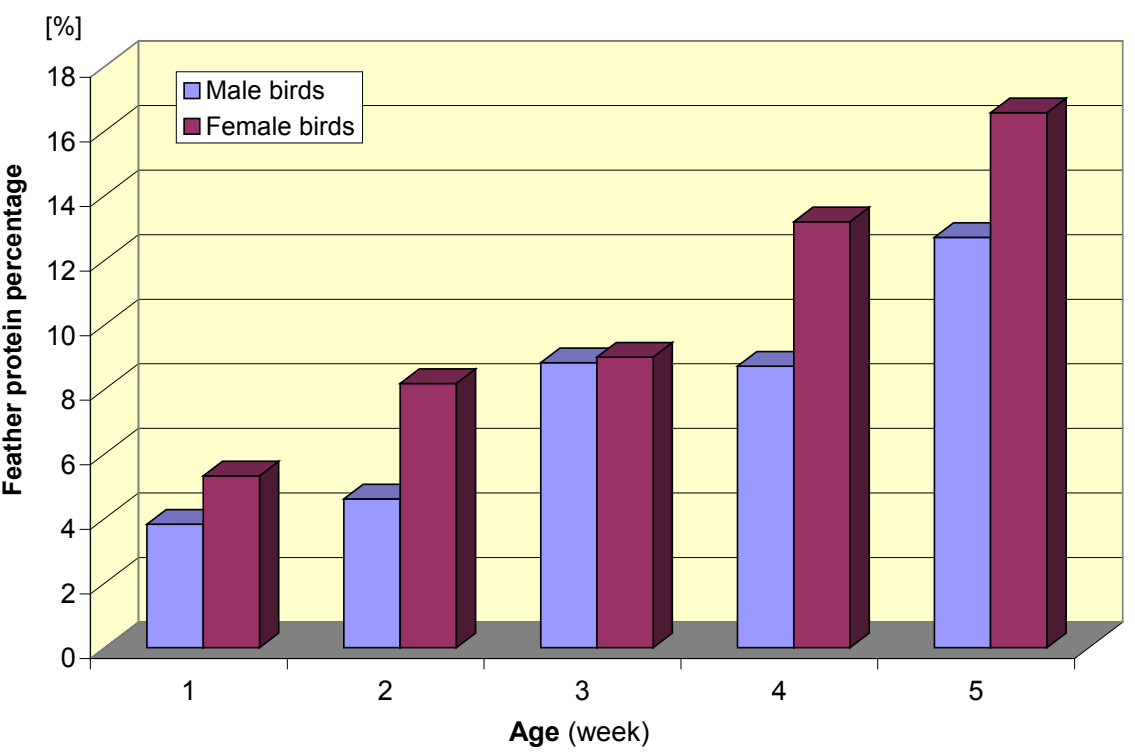

Figure 1. Feather protein as related to the whole body protein deposition (in \%) of growing broiler chickens depending on age and gender.

\section{Discussion}

During the entire experimental period, the mean daily FI of male birds was in line with the performance objectives of the Ross 308 broiler [15]. However, female birds continuously yielded superior FI levels during weeks 2 to 5 as compared to these recommendations, but no significant gender specific effect $(p>$ 0.05) was obtained in the present study (Table 1). Except for week 1, the observed mean daily BWG of both genders was in parts considerably higher than recommended [15]. The initially superior growth rate of females compared to male birds was likely the consequence of their slightly higher hatch weight and their higher feed intake during the first 2 weeks. The observed zoo-technical results had an advantageous impact on FCR data, especially during the last 3 weeks of the experimental period. As expected, the FCR of male birds was significantly better $(p=0.001)$ than that of females, and with increasing age inferior FCR results $(p<0.001)$ were yielded for both genders.

As already reported [4], it is well-known that the body composition of growing broiler chickens can be altered through the modulation of the dietary protein and energy supply as well as by animal-specific factors of influence. Similar effects could be expected for nutrient and energy deposition being dependent on the level of protein and energy intake. Lowering dietary CP in the feed has been shown to significantly increase body fat deposition in broiler chickens [16]-[21]. Even when trials have included protein reduced diets with supplemented free AA, an observed significant increase in fat deposition could not be prevented [22]-[27]. Similarly, the PD was not or only slightly influenced by these experimental conditions. In contrast, significantly higher body protein was accumulated with diets balanced according to the recommended AA requirement [21] [27]-[35]. 
All these observations underline the importance of accurately formulating diets to ensure an ideal dietary AA balance according to the real requirement dependent on age and gender. By feeding such diets, the entire growth period of up to 5 weeks lead to male broiler chickens depositing on average between 11 and $13 \mathrm{~g}$ protein per day in the whole body [34] [35] [36]. These results as well as the data (6 to 9 g PD per day) derived for the starter period [25] [27] [28] [32] [33] are closely aligned to our estimated values (Table 2). Further literature data relating to the nutrient and energy deposition in broiler chickens are not comparable because in such studies usually shorter BW ranges and different feeding strategies, including marginal and excessive nutrient supply, was examined. Therefore, in the majority of these investigations lower body protein and extremely variable body fat resp. body energy contents were obtained [17] [24] [28] [29] [30] [37] [38] [39] [40] as compared to our observed age and gender dependent deposition data. Predominantly, these results were attributed to the lower performance potential of earlier broiler genotypes or to the different genetic predisposition of growing chickens under study [20] [33] [38] [41] [42] [43]. However, in the literature it has been clearly documented that higher body fat deposition in birds was induced through higher energy supply (e.g. [16] [17] [18] [30] [32] [39] [44]. For example, as compared to our mean value for male birds and the entire growth period of 5 weeks, a markedly higher body energy deposition has been reported exceeding $600 \mathrm{~kJ} / \mathrm{d}$ [35] or $700 \mathrm{~kJ} / \mathrm{d}$ [36].

Furthermore, the observations that female broilers accumulate significantly more body fat and lower body protein than their male counterparts [9] [38] [42], as indicated by our data (Table 2), show that the gender of birds must be taken into account when nutrient deposition in the body of birds is being evaluated. Likewise, the observed influence that the deposition of protein, fat and energy significantly increased with increasing age confirmed results of other investigations [16] [17] [30] [38] [43] [45] [46]. Regarding the body CA deposition, it can be stated that given the relatively limited data found in the literature [29] [35] [36] our observations are within range of expected results.

In order to estimate the nutrient and energy content in the gain of birds based on BW data observed in growth experiments, the difference between the individual empty BW as a reference for the nutrient composition and the whole BW prior to feed withdrawal must be estimated. In the present experiment a mean BW loss between $7 \%$ and $9 \%$ after 24 hours feed deprivation as related to the BW (live weight at free access to feed) immediate prior to feed withdrawal was calculated (Table 3). In contrast, for birds both of both genders at the age of $8 \mathrm{~d}$ a range from $13 \%$ to $14 \% \mathrm{BW}$ loss was recorded. This divergent result for these very young chickens is not described in the literature, but could be possibly attributed to the role of the yolk sac during the first week in a chicken's life. Generally, the BW loss of birds is predominantly affected by the emptying of the digestive tract, and increases progressively with the time of feed deprivation [47]-[60]. 
Consistent with our experimental approach, after a fasting period of $24 \mathrm{~h}$ without access to feed, the BW loss of broiler chickens at market age has been shown to vary between $6 \%$ and $10 \%$ [47] [48] [57] [58] [59] [61]. Our study reports values in reasonably good agreement with this range. However despite this narrow range, even slightly lower (below 6\% [49] [53]) and higher values (at about $13 \%$ after $16 \mathrm{~h}$ feed deprivation [53]) of BW loss have been reported. The reasons of this extremely high variability are multifaceted. Alone, the definitions of BW loss do not remain consistent, and therefore comparable, throughout the literature. This may often have to do with variable conditions pre- and post-fasting or them not being described in full detail. Furthermore, the BW loss following feed deprivation depends considerably on holding conditions [52] [54] [55] [62] and the age of the birds [55] [60]. Additionally, it is also affected by the gender [48] [54] [60] [62] [63], whereby higher weight loss for male chickens has been detected. The influence of the latter two factors was confirmed by our results (Table 3); although other studies have reported no effect of sex on BW loss after feed deprivation [51] [55]. Finally, different transit times of the feed through the gastrointestinal tract dependent on ingredient composition, dietary quality and the level of individual feed intake prior to feed deprivation must be taken into account.

The derived protein composition of the BWG of birds during the entire growth period (Table 4) is in good agreement with the summarized overview of GRRS [9] and with more recent literature values [27] [33] [64], which indicate a range between 156 to $202 \mathrm{~g} \mathrm{CP} / \mathrm{kg}$ BWG from 1 to 5 weeks of age. Nieß et al. [26] even found values of up to $212 \mathrm{~g}$ protein per $\mathrm{kg}$ weight gain in male broiler chickens during the grower period from 21 to $42 \mathrm{~d}$ of age. In the German recommendations for poultry nutrition [9] no different protein content in the BWG between male and female birds was documented, and this recommendation can be considered advisable given our insignificant gender dependent data ( $p>$ $0.05)$. In contrast, our calculated CL contents in the gained BW are considerably lower, especially for male broiler chickens, as compared with the reported data between 100 to $168 \mathrm{~g} \mathrm{CL} / \mathrm{kg} \mathrm{BWG} \mathrm{[9]} \mathrm{[26]} \mathrm{[27]} \mathrm{[33]} \mathrm{[64].} \mathrm{The} \mathrm{literature} \mathrm{values}$ for female birds were superior to male birds, yet markedly higher (115 to $189 \mathrm{~g}$ $\mathrm{CL} / \mathrm{kg}$ BWG [9]) than those listed in Table 4.

In the present study, the quantitative protein gain, both in feathers and feather-free body components, consistently increasing with age also conformed with previous literature [9] [32] [65] [66]. However, Gous et al. [42] and Bonato et al. [67] have postulated that the rate of feather protein gain during growth is higher than that for body protein. As already discussed [4] [5], the partitioning of protein in muscle tissues, organs and feathers is differentiates as age advances. Although the fresh feather mass represents only a small part of the empty BW ( $2 \%$ to $4 \%$ [6]), the contribution of feather protein deposition in proportion to the total body protein deposition ranged accordingly (Table 5) from average $4.6 \%$ during week 1 (mean $\mathrm{BW}=120 \mathrm{~g}$ ) to an average of $14.6 \%$ during week 5 
(mean $\mathrm{BW}=2100 \mathrm{~g}$ ). These data are in good agreement with values between $7.0 \%$ and $18.8 \%$ feather protein in the accreted whole body protein of 1 - 5 week old birds [9] or a deposited proportion of $11 \%$ to $13 \%$ feather protein during the starter and grower period, respectively [32]. Therefore, it can be concluded from our results that the relative proportion of PD in the feather-free body (Figure 1) as well as in individual organs [32] decreases with increasing age.

Despite comparable protein contents in the BWG for both genders, differences were found in the partitioning of the accreted amount of feather and feather-free body protein. Female birds deposited more protein absolutely in their feather fraction and had significantly more feather protein per unit BWG as compared to males. These results can be attributed to the relatively higher proportion of the feather fraction and the lower feather-free body fraction in female birds with increasing age [4].

Beside this gender-specific difference, it must be taken into account that the nutrient supply preferentially impacts on feather growth, feather $\mathrm{N}$ content and feather protein gain [68] [69] resulting in a considerably higher "luxury deposition" of protein in the feather fraction of birds receiving the highest protein supply [17].

\section{Conclusions}

The results of our present investigation indicated that the mean daily nutrient and energy deposition in the whole body of Ross 308 broiler chickens was significantly increased with increasing age from week 1 to week 5. Male birds achieved significantly higher body CP and CA deposition, especially during the last 3 weeks. In contrast, female birds contained consistently higher CL and energy deposition in the whole body during the weekly growth periods.

Throughout the study, the CP composition of the BWG was remained insignificant between both genders, but the protein partitioning in the feather and feather-free body fraction provided oppositional results. Male chickens yielded higher quantities of protein in the feather-free body and females had relatively more feather protein in the gained BW. Consequently, the feather protein percentage must be supposed as a variable parameter, especially during the rapid growth period of birds. These characteristics should be carefully considered in AA requirement studies because both protein fractions exhibit marked differences in the composition of individual AAs.

\section{Conflicts of Interest}

The authors declare no conflicts of interest regarding the publication of this paper.

\section{References}

[1] Havenstein, G.B., Ferket, P.R. and Qureshi, M.A. (2003) Carcass Composition and Yield of 1957 Versus 2001 Broilers When Fed Representative 1957 And 2001 Broiler Diets. Poultry Science, 82, 1509-1518. https://doi.org/10.1093/ps/82.10.1509 
[2] Schmidt, C.J., Persia, M.E., Feierstein, E., Kingham, B. and Saylor, W.W. (2009) Comparison of a Modern Broiler Line and a Heritage Line Unselected Since the 1950s. Poultry Science, 88, 2610-2619. https://doi.org/10.3382/ps.2009-00055

[3] Liebert, F. (2017) Further Progress Is Needed in Procedures for the Biological Evaluation of Dietary Protein Quality in Pig and Poultry Feeds. Archives Animal Breeding, 60, 259-270. https://doi.org/10.5194/aab-60-259-2017

[4] Wecke, C., Khan, D.R., Sünder, A. and Liebert, F. (2018) Age and Gender Dependent Nutrient Composition of Feather and Feather-Free Body Fractions in Meat-Type Chickens. Open Journal of Animal Sciences, 8, 74-86. https://doi.org/10.4236/ojas.2018.81006

[5] Wecke, C., Khan, D.R., Sünder, A. and Liebert, F. (2018) Age and Gender Dependent Amino Acid Concentrations in the Feather, Feather-Free and Whole Empty Body Protein of Fast Growing Meat-Type Chickens. Open Journal of Animal Sciences, 8, 223-238. https://doi.org/10.4236/ojas.2018.83017

[6] Wecke, C., Khan, D.R., Sünder, A. and Liebert, F. (2017) Age and Gender Depending Growth of Feathers and Feather-Free Body in Modern Fast Growing Meat-Type Chickens. Open Journal of Animal Sciences, 7, 376-392.

https://doi.org/10.4236/ojas.2017.74029

[7] Aviagen (2014) Ross Broiler Management Handbook. Aviagen Group, Huntsville. http://en.aviagen.com/assets/Tech_Center/Ross_Broiler/Ross-Broiler-Handbook-20 14i-EN.pdf

[8] NRC (1994) Nutrient Requirements of Poultry. 9th Revised Edition, National Research Council, National Academy Press, Washington DC.

[9] GRRS (German Recommendations for Requirement Standards) Gesellschaft für Ernährungsphysiologie, Ausschuss für Bedarfsnormen (1999) Empfehlungen zur Energie- und Nährstoffversorgung der Legehennen und Masthühner (Broiler). DLG-Verlags-GmbH, Frankfurt am Main, Germany.

[10] Aviagen (2014) Ross 308 Broiler: Nutrition Specifications. Aviagen Group, Huntsville.

http://en.aviagen.com/assets/Tech_Center/Ross_Broiler/Ross-308-Broiler-Nutrition -Specs-2014r17-EN.pdf

[11] Wecke, C. and Liebert, F. (2013) Improving the Reliability of Optimal In-Feed Amino Acid Ratios Based on Individual Amino Acid Efficiency Data from N Balance Studies in Growing Chicken. Animals, 3, 558-573. https://doi.org/10.3390/ani3030558

[12] Naumann, C. and Bassler, R. (1976-2004) Die chemische Untersuchung von Futtermitteln. [The Chemical Analysis of Feedstuffs.] Methodenbuch, Vol. III, VDLUFA-Verlag, Darmstadt.

[13] The Commission of the European Communities (2009) Commission Regulation (EC) No 152/2009 of 27 January 2009 Laying Down the Methods of Sampling and Analysis for the Official Control of Feed. Official Journal of the European Union, L54/1-L54/130.

[14] Fuller, M.F., Ed. (2004) The Encyclopedia of Farm Animal Nutrition. CABI Publishing, Wallingford, Oxon, UK. https://doi.org/10.1079/9780851993690.0000

[15] Aviagen (2014) Ross 308 Broiler: Performance Objectives. Aviagen Group, Huntsville.

http://en.aviagen.com/assets/Tech_Center/Ross_Broiler/Ross-308-Broiler-PO-2014EN.pdf

[16] Gerum, J. and Kirchgeßner, M. (1978) Protein, Fat and Energy Deposition of Two 
Weeks Old Broilers with Varying Energy and Protein Supply. Archiv für Geflügelkunde, 42, 22-28. (In German)

[17] Kirchgeßner, M., Roth-Maier, D.A. and Gerum, J. (1978) Body Composition and Nutrient Deposition of 3-5 Week Old Broilers with Varying Energy and Protein Supply. Archiv für Geflügelkunde, 42, 62-69. (In German)

[18] Jackson, S., Summers, J.D. and Leeson, S. (1981) Effect of Dietary Protein and Energy on Broiler Carcass Composition and Efficiency of Nutrient Utilization. Poultry Science, 61, 2224-2231. https://doi.org/10.3382/ps.0612224

[19] Rosebrough, R.W. and Steele, N.C. (1985) Energy and Protein Relationships in the Broiler. 1. Effect of Protein Levels and Feeding Regimens on Growth, Body Composition, and In Vitro Lipogenesis of Boiler Chicks. Poultry Science, 64, 119-126. https://doi.org/10.3382/ps.0640119

[20] Geraert, P.A., Macleod, M.G., Larbier, M. and Leclercq, B. (1990) Nitrogen Metabolism in Genetically Fat and Lean Chickens. Poultry Science, 69, 1911-1921. https://doi.org/10.3382/ps.0691911

[21] Aletor, V.A., Hamid, I.I., Nieß, E. and Pfeffer, E. (2000) Low-Protein Amino Acid-Supplemented Diets in Broiler Chickens: Effects on Performance, Whole-Body Composition and Efficiencies of Nutrient Utilization. Journal of the Science of Food and Agriculture, 80, 547-554.

https://doi.org/10.1002/(SICI)1097-0010(200004)80:5<547::AID-JSFA531>3.0.CO;2-C

[22] Summers, J.D. and Leeson, S. (1985) Broiler Carcass Composition as Affected by Amino Acid Supplementation. Canadian Journal of Animal Science, 65, 717-723. https://doi.org/10.4141/cjas85-084

[23] Fancher, B.I. and Jensen, L.S. (1989) Influence on Performance of Three to Six-Week-Old Broilers of Varying Dietary Protein Contents with Supplementation of Essential Amino Acid Requirements. Poultry Science, 68, 113-123. https://doi.org/10.3382/ps.0680113

[24] Deschepper, K. and De Groote, G. (1995) Effect of Dietary Protein, Essential and Non-Essential Amino Acids on the Performance and Carcase Composition of Male Broiler Chickens. British Poultry Science, 36, 229-245. https://doi.org/10.1080/00071669508417772

[25] Bregendahl, K., Sell, J.L. and Zimmerman, D.R. (2002) Effect of Low-Protein Diets on Growth Performance and Body Composition of Broiler Chicks. Poultry Science, 81, 1156-1167. https://doi.org/10.1093/ps/81.8.1156

[26] Nieß, E., Hamid, I.I. and Pfeffer, E. (2003) Effect of Non Essential Amino Acid Supply on the Deposition of Protein and Lipids in Broiler Chicks. Archiv für Geflügelkunde, 67, 167-174.

[27] Fatufe, A.A. and Rodehutscord, M. (2005) Growth and Body Composition, and Marginal Efficiency of Methionine Utilization Are Affected by Nonessential Amino Acid Nitrogen Supplementation in Male Chicken. Poultry Science, 84, 1584-1592. https://doi.org/10.1093/ps/84.10.1584

[28] Velu, J.G., Scott, H.M. and Baker, D.H. (1972) Body Composition and Nutrient Utilization of Chicks Fed Amino Acid Diets Containing Graded Amounts of Either Isoleucine or Lysine. The Journal of Nutrition, 102, 741-748.

https://doi.org/10.1093/jn/102.6.741

[29] Sibbald, I.R. and Wolynetz, M.S. (1986) Effects of Dietary Lysine and Feed Intake on Energy Utilization and Tissue Synthesis by Broiler Chicks. Poultry Science, 65, 98-105. https://doi.org/10.3382/ps.0650098

[30] Holsheimer, J.P. and Ruesink, E.W. (1993) Effect on Performance, Carcass Compo- 
sition, Yield, and Financial Return of Dietary Energy and Lysine Levels in Starter and Finisher Diets Fed to Broilers. Poultry Science, 72, 806-815.

https://doi.org/10.3382/ps.0720806

[31] Edwards, H.M. III and Baker, D.H. (1999) Maintenance Sulfur Amino Acid Requirements of Young Chicks and Efficiency of Their Use for Accretion of Whole-Body Sulfur Amino Acids and Protein. Poultry Science, 78, 1418-1423. https://doi.org/10.1093/ps/78.10.1418

[32] Eits, R.M., Kwakkel, R.P., Verstegen, M.W.A., Stoutjesdijk, P. and De Greef, K.H. (2002) Protein and Lipid Deposition Rates in Male Broiler Chickens: Separate Responses to Amino Acids and Protein-Free Energy. Poultry Science, 81, 472-480. https://doi.org/10.1093/ps/81.4.472

[33] Fatufe, A.A., Timmler, R. and Rodehutscord, M. (2004) Response to Lysine Intake in Composition of Body Weight Gain and Efficiency of Lysine Utilization of Growing Male Chickens from Two Genotypes. Poultry Science, 83, 1314-1324. https://doi.org/10.1093/ps/83.8.1314

[34] Neumann, C., Velten, S. and Liebert, F. (2018) The Graded Inclusion of Algae (Spirulina platensis) or Insect (Hermetiaillucens) Meal as a Soybean Meal Substitute in Meat Type Chicken Diets Impacts on Growth, Nutrient Deposition and Dietary Protein Quality Depending on the Extent of Amino Acid Supplementation. Open Journal of Animal Sciences, 8, 163-183. https://doi.org/10.4236/ojas.2018.82012

[35] Velten, S., Neumann, C., Schäfer, J. and Liebert, F. (2018) Effects of the Partial Replacement of Soybean Meal by Insect or Algae Meal in Chicken Diets with Graded Amino Acid Supply on Parameters of Gut Microbiology and Dietary Protein Quality. Open Journal of Animal Sciences, 8, 259-279. https://doi.org/10.4236/ojas.2018.83020

[36] Muhl, A. and Liebert, F. (2007) Growth, Nutrient Utilization and Threonine Requirement of Growing Chicken Fed Threonine Limiting Diets with Commercial Blends of Phytogenic Feed Additives. The Journal of Poultry Science, 44, 297-304. https://doi.org/10.2141/jpsa.44.297

[37] Strohschneider, R. (1981) Feed Protein and Amino Acid Utilization in Growing Chickens Depending on Dietary Protein Content. PhD Thesis, Georg-August-Universität Göttingen, 135.

[38] Cahaner, A. and Leenstra, F. (1992) Effect of High Temperature on Growth and Efficiency of Male and Female Broilers from Lines Selected for High Weight Gain, Favourable Feed Conversion, and High or Low Fat Content. Poultry Science, 71, 1237-1250. https://doi.org/10.3382/ps.0711237

[39] Liebert, F. (1995) Influence of Different Energy Supply on Nutrient and Energy Utilization of Broilers. Archiv für Geflügelkunde, 59, 269-273. (In German)

[40] Webel, D.M., Johnson, R.W. and Baker, D.H. (1998) Liposaccharide-Induced Reductions in Body Weight Gain and Feed Intake Do Not Reduce the Efficiency of Arginine Utilization for Whole-Body Protein Accretion in the Chick. Poultry Science, 77, 1893-1898. https://doi.org/10.1093/ps/77.12.1893

[41] Leclercq, B., Chagneau, A.M., Cochard, T. and Khoury, J. (1994) Comparative Responses of Genetically Lean and Fat Chickens to Lysine, Arginine and Non-Essential Amino Acid Supply. I. Growth and Body Composition. British Poultry Science, 35, 687-696. https://doi.org/10.1080/00071669408417735

[42] Gous, R.M., Moran Jr., E.T., Stilborn, H.R., Bradford, G.D. and Emmans, G.C. (1999) Evaluation of the Parameters Needed to Describe the Overall Growth, the Chemical Growth, and the Growth of Feathers and Breast Muscles of Broilers. 
Poultry Science, 78, 812-821. https://doi.org/10.1093/ps/78.6.812

[43] Lopez, G., de Lange, K. and Leeson, S. (2007) Partitioning of Retained Energy in Broilers and Birds with Intermediate Growth Rate. Poultry Science, 86, 2162-2171.

[44] Boekholt, H.A., van der Grinten, P., Schreurs V.V.A.M., Los, M.J.N. and Leffering, C.P. (1994) Effect of Dietary Energy Restriction on Retention of Protein, Fat and Energy in Broiler Chickens. British Poultry Science, 35, 603-614. https://doi.org/10.1080/00071669408417725

[45] Leeson, S. and Summers, J.D. (1980) Production and Carcass Characteristics of the Broiler Chicken. Poultry Science, 59, 786-798. https://doi.org/10.3382/ps.0590786

[46] Xi, P.B., Yi, G.F., Lin, Y.C., Zheng, C.T., Jiang, Z.Y. Vazques-Anon, M., Song, G.L. and Knight, C.D. (2007) Effect of Methionine Source and Dietary Crude Protein Level on Growth Performance, Carcass Traits and Nutrient Retention in Chinese Color-Feathered Chicks. Asian-Austalasian Journal of Animal Science, 20, 962-970. https://doi.org/10.5713/ajas.2007.962

[47] Smidt, M.J., Formica, S.D. and Fritz, J.C. (1964) Effect of Fasting Prior to Slaughter on Yield of Broilers. Poultry Science, 43, 931-934.

https://doi.org/10.3382/ps.0430931

[48] Häseler, F. and Requart, E. (1968) Studies on the Influence of Different Fasting intervals on the Slaughtering Results of Chicken Broilers. Archiv für Geflügelzucht und Kleintierkunde, 17, 269-290. (In German)

[49] Wabeck, C.J. (1972) Feed and Water Withdrawal Time Relationship to Processing Yield and Potential Fecal Contamination of Broilers. Poultry Science, 51, 1119-1121. https://doi.org/10.3382/ps.0511119

[50] Veerkamp, C.H. (1978) The Influence of Fasting and Transport on Yields of Broilers. Poultry Science, 57, 634-638. https://doi.org/10.3382/ps.0570634

[51] Summers, J.D. and Leeson, S. (1979) Comparison of Feed Withdrawal Time and Passage of Gut Contents in Broiler Chickens Held in Crates or Litter Pens. Canadian Journal of Animal Science, 59, 63-66. https://doi.org/10.4141/cjas79-007

[52] Fletcher, D.L. and Rahn, A.P. (1982) The Effect of Environmentally Modified and Conventional Housing Types on Broiler Shrinkage. Poultry Science, 61, 67-74. https://doi.org/10.3382/ps.0610067

[53] Jensen, L.S., Cervantes, H.M. and Takahashi, K. (1984) Liver Lipid Content in Broilers as Affected by Time without Feed or Feed and Water. Poultry Science, 63, 2404-2407. https://doi.org/10.3382/ps.0632404

[54] Benibo, B.S. and Farr, A.J. (1985) The Effects of Feed and Water Withdrawal and Holding Shed Treatments on Broiler Yield Parameters. Poultry Science, 64, 920-924. https://doi.org/10.3382/ps.0640920

[55] Veerkamp, C.H. (1986) Fasting and Yield of Broilers. Poultry Science, 65, 1299-1304. https://doi.org/10.3382/ps.0651299

[56] Rasmussen, A.L. and Mast, M.G. (1989) Effect of Feed Withdrawal on Composition and Quality of Broiler Meat. Poultry Science, 68, 1109-1113. https://doi.org/10.3382/ps.0681109

[57] Lyon, C.E., Papa, C.M. and Wilson Jr., R.L. (1991) Effect of Feed Withdrawal on Yields, Muscle pH, and Texture of Broiler Breast Meat. Poultry Science, 70, 1020-1025. https://doi.org/10.3382/ps.0701020

[58] Papa, C.M. (1991) Lower Gut Contents of Broiler Chickens Withdrawn from Feed and Held in Cages. Poultry Science, 70, 375-380. https://doi.org/10.3382/ps.0700375

[59] Buhr, R.J., Northcutt, J.K., Lyon, C.E. and Rowland, G.N. (1998) Influence of Time 
off Feed on Broiler Viscera Weight, Diameter, and Shear. Poultry Science, 77, 758-764. https://doi.org/10.1093/ps/77.5.758

[60] Northcutt, J.K., Buhr, R.J., Berrang, M.E. and Fletcher, D.L. (2003) Effects of Replacement Finisher Feed and Length of Feed Withdrawal on Broiler Carcass Yield and Bacteria Recovery. Poultry Science, 82, 1820-1824.

https://doi.org/10.1093/ps/82.11.1820

[61] Warriss, P.D., Wilkins, L.J., Brown, S.N., Phillips, A.J. and Allen, V. (2004) Defaecation and Weight of the Gastrointestinal Tract Contents after Feed and Water Withdrawal in Broilers. British Poultry Science, 45, 61-66. https://doi.org/10.1080/0007166041668879

[62] Chen, T.C., Schultz, C.D., Reece, F.N., Lott, B.D. and McNaughton, J.L. (1983) The Effect of Extended Holding Time, Temperature, and Dietary Energy on Yields of Broilers. Poultry Science, 62, 1566-1571. https://doi.org/10.3382/ps.0621566

[63] Moran Jr., E.T. and Bilgili, S.F. (1990) Processing Losses, Carcass Quality, and Meat Yields of Broiler Chickens Receiving Diets Marginally Deficient to Adequate in Lysine Prior to Marketing. Poultry Science, 69, 702-710. https://doi.org/10.3382/ps.0690702

[64] Conde-Aguilera, J.A., Cobo-Ortega, C., Tesseraud, S., Lessire, M., Mercier, Y. and van Milgen, J. (2013) Changes in Body Composition in Broilers by a Sulphur Amino Acid Deficiency during Growth. Poultry Science, 92, 1266-1275. https://doi.org/10.3382/ps.2012-02796

[65] Hurwitz, S., Sklan, D. and Bartov, I. (1978) New Formal Approaches to the Determination of Energy and Amino Acid Requirements of Chicks. Poultry Science, 57, 197-205. https://doi.org/10.3382/ps.0570197

[66] Sakomura, N.K., Silva, E.P., Dorigam, J.C.P., Gous, R.M. and St-Pierre, N. (2015) Modeling Amino Acid Requirements of Poultry. The Journal of Applied Poultry Research, 24, 267-282. https://doi.org/10.3382/japr/pfv024

[67] Bonato, M.A., Sakomura, N.K., Gous, R.M., Silva, E.P., Soares, L. and Peruzzi, N.J. (2016) Description of a Model to Optimise the Feeding of Amino Acids to Growing Pullets. British Poultry Science, 57, 123-133. https://doi.org/10.1080/00071668.2015.1127892

[68] Wylie, L.M., Robertson, G.W. and Hocking, P.M. (2003) Effects of Dietary Protein Concentration and Specific Amino Acids on Body Weight, Body Composition and Feather Growth in Young Turkeys. British Poultry Science, 44, 75-87. https://doi.org/10.1080/0007166031000085346

[69] Urdaneta-Rincon, M. and Leeson, S. (2004) Effect of Dietary Crude Protein and Lysine on Feather Growth in Chicks to Twenty-One Days of Age. Poultry Science, 83, 1713-1717. https://doi.org/10.1093/ps/83.10.1713 